\title{
Boosting Sperm Count Using Red Ginger in Mice Induced by Paraquat Dichloride (1.1-dimethyl-4.4 bipyridinium)
}

\author{
Siti Umairoh, *Sutyarso, M. Kanedi, Hendri Busman
}

Jurusan Biologi, FMIPA, Universitas Lampung

Jalan Prof. Dr. Soemantri Brodjonegoro No. 1 Bandar Lampung, Lampung 35145

*Email: sutyarso@yahoo.co.id

\begin{abstract}
Paraquat dichloride (1.1'-dimethyl-4.4'-bipyridinium dichloride) was commonly herbicide used by most farmers in Indonesia. It raises herbicide-free radicals and affects male reproductive organs. It caused infertility such as a decrease in the number of spermatogenic cells. Fortunately, red ginger has capable of dealing with infertility problems. This study aims to see whether the ethanol extract of red ginger can increase the number of spermatocyte and spermatid cells induced by paraquat dichloride. This study uses a completely randomized design with 24 male mice were divided into six treatment groups with four replications. Group K as a control (H2O), J (Ginger $18 \mathrm{mg} / \mathrm{ml}$ ), Pq (Paraquat 20mg / BB), P1 (Pq $20 \mathrm{mg}$ / BB + EEJM $6 \mathrm{mg} / \mathrm{ml}$ ), P2 (Paraquat 20mg / BB + EEJM $12 \mathrm{mg} / \mathrm{ml}$ ) and P3 (Paraquat $20 \mathrm{mg} / \mathrm{BB}+\mathrm{EEJM} 18 \mathrm{mg} / \mathrm{ml}$ ). Paraquat is given 2 times a week for 21 days, while the ethanol extract of red ginger added for 35 days. The number of cells spermatocyte and spermatid cells of male mice and performed analysis of variance (ANOVA) and Least Significant Difference Test (BNT) level of $5 \%$ observed as the parameter. The results showed that ethanol extract of red ginger 6,12 and $18 \mathrm{mg} / \mathrm{ml}$ increased the number of spermatocyte and spermatid cells of male mice induced by paraquat dichloride.
\end{abstract}

Keywords: infertility, red ginger, spermatogenic cells, Mus musculus L., paraquat dichloride

\section{PENDAHULUAN}

Penerapan agrokimia berupa penggunaan herbisida di bidang pertanian merupakan suatu cara yang lazim dilakukan oleh para petani. Hal itu merupakan salah satu upaya dalam pengendalian hama maupun pemupukan tanaman untuk meningkatkan hasil pertanian yang optimal. Petani merupakan kelompok kerja terbesar di berbagai negara di dunia termasuk di Indonesia (Prijanto, 2009).

Herbisida yang banyak digunakan pada bidang pertanian dan perkebunan adalah jenis paraquat (1,1-dimethyl,4,4bipyridylium). Paraquat merupakan salah satu bahan aktif herbisida jenis gramoxone yang telah lama dan sampai saat ini paling banyak digunakan dalam budidaya tanaman di seluruh dunia, termasuk di Indonesia. Dipicu oleh semakin langkanya tenaga kerja dan tersedianya herbisida yang relatif mudah dan murah, peningkatan penggunaan pestisida di Indonesia, khususnya herbisida, semakin terlihat nyata pada 20 tahun terakhir. Tingginya intensitas aplikasi dan jumlah herbisida yang diaplikasikan menimbulkan kekhawatiran yang cukup besar mengenai bahaya pencemaran yang berasal dari residu herbisida yang tertinggal di lingkungan, khususnya dalam tanah dan air. Selain itu herbisida juga dapat masuk ke dalam tubuh manusia melalui beberapa cara yaitu dapat melalui oral/mulut, respirasi/pernapasan, dan penetrasi kulit yang dikhawatirkan akan menimbulkan gangguan kesehatan bagi manusia (Sriyani \& Salam, 2008). 
Permasalahan mengenai gangguan kesehatan pada manusia akibat dari peningkatan penggunaan herbisida di lingkungan menimbulkan terbentuknya radikal bebas. Hal ini disebabkan herbisida paraquat yang masuk ke dalam tubuh akan menyebabkan induksi toksisitas dikarenakan kemampuannya untuk mempengaruhi siklus redoks dan membentuk Reactive Oxygen Species (ROS) yang mengakibatkan masalah infertilitas (Kartikeya, 2009).

Pada pasangan yang mengalami infertilitas tentunya secara pasti akan menjalani berbagai pengobatan untuk dapat mempunyai keturunan. Untuk melihat kesuburan pada pria dapat dilihat dari kemampuan spermatozoa yang dihasilkan dalam melakukan proses fertilisasi. Adapun faktor yang mempengaruhi proses tersebut yaitu kemampuan organ dan hormon yang mempengaruhi proses reproduksi untuk bekerja secara optimal. Pengoptimalan kerja dari organ dan hormon reproduksi selain dipengaruhi oleh unsur genetik juga dipengaruhi oleh faktor lingkungan (Hardjopranjoto, 1995).

Dalam mengatasai permasalahan infertilitas diperlukan suatu tanaman obat yang meiliki kandungan antioksidan untuk menangani kasus infertilitas yang terjadi. Terapi kasus infertilitas lebih banyak menggunakan tanaman herbal karena memiliki efek samping yang minimal. Salah satu tanaman yang dipercayai mengandung zat antioksidan dan mampu mengatasi permasalahan reproduksi yang diakibatkan oleh pengaruh radikal bebas adalah tanaman Jahe (Zingiber officinale Roxb. var. rubrum). Jahe merupakan salah satu tumbuhan yang berasal dari suku Zingiberaceae, jahe memilki posisi yang penting dalam berbagai aspek antara lain aspek kesehatan dan perekonomian, aspek kegunaan, adat serta kepercayaan sebagai tumbuhan etnobotani dalam masyarakat Indonesia. Jahe banyak digunakan sebagai tumbuhan tradisional yang dikonsumsi masyarakat sebagai minuman dan bahan makaanan, bahan pewarna serta obat-obatan (Palaniyappan et al., 2013) Tanaman jahe merah merupakan salah satu tanaman obat yang mempunyai kandungan antioksidan yang kuat dan mampu mengurangi serta mencegah terbentuknya radikal-radikal bebas. Sebagai hasil dari aktivitas antioksidanya, jahe merah akan memacu aktivitas androgenik untuk organ testis sebagai hasil dari peningkatan hormone $\mathrm{LH}, \mathrm{FSH}$, dan testoteron (Ali et al., 2008).

Hal ini yang melatarbelakangi peneliti untuk membuktikan bahwa jahe merah (Zingiber officinale Roxb. var. rubrum) dapat meningkatkan jumlah sel spermatogenik mencit (Mus musculus L.) jantan yang diinduksi herbisida paraquat. Penelitian ini bertujuan untuk mengetahui efek pemberian ekstrak etanol jahe merah (Zingiber officinale Roxb. var. rubrum) terhadap jumlah sel spermatosit dan sel spermatid yang dinduksi herbisida paraquat.

\section{METODE PENELITIAN}

\section{Bahan}

Bahan yang digunakan dalam penelitian ini adalah rimpang jahe merah sebanyak $1 \mathrm{~kg}$ yang diperoleh dari pembudidaya jahe merah di daerah Bataranila Lampung. Selain itu bahan kimia lainnya yang dipakai untuk menginduksi hewan uji adalah paraquat diklorida yang diperoleh melalui toko pertanian di jalan Teuku Umar, Lampung.

\section{Pembuatan ekstrak jahe merah}

Proses pembuatan ekstrak jahe merah dalam penelitian ini mengunakan etanol 96\% sebagai pelarut. Ekstraksi jahe dibuat dengan menggunakan metode ekstraksi basah. Ekstraksi dimulai dari penimbangan jahe merah. Selanjutnya jahe dikupas dan dicuci dengan menggunakan aquadest setelah itu dipotong-potong tipis dan kemudian dikeringanginkan dibawah sinar matahari hingga kering. Selanjutnya jahe yang sudah dipotong diletakkan ke dalam wadah atau beaker glass berukuran 1 liter. Kemudian ditambahkan etanol 
teknis dengan kadar 96\% untuk melakukan ekstraksi basah ini didiamkan selama 24 jam dan diaduk setiap 6 jam sekali. Setelah itu hasil filtratnya ditampung pada erlenmeyer dan ampasnya juga ditampung dan disaring dengan kertas saring pada bejana yang berbeda untuk dapat dipakai kembali dalam ekstraksi basah. Filtrat yang didapat akan diteruskan ke tahap evaporasi yang dilakukan di laboratorium instrumentasi jurusan Kimia FMIPA, Universitas Lampung sehingga akhirnya diperoleh ekstrak kental.

\section{Hewan uji dan rancangan percobaan}

Pada penelitian ini kami menggunakan hewan uji Mencit (Mus musculus L.) jantan sebanyak 24 ekor dengan berat badan berkisar 30-40gram dengan kondisi sehat. Mencit-mencit tersebut dibagi menjadi 6 kelompok perlakuan dan masing-masing terbagi menjadi 4 ulangan. Kelompok perlakuan tersebut, yaitu:

1. Kelompok $\mathbf{K}$ sebagai kontrol $\left(\mathrm{H}_{2} \mathrm{O}\right)$,

2. Kelompok J (Jahe18 mg/ml),

3. Kelompok Pq (Paraquat 20mg/ $\mathrm{BB})$,

4. Kelompok P1 (Pq 20 mg/BB + EEJM 6 mg/ml),

5. Kelompok P2 (Paraquat 20mg/BB + EEJM $12 \mathrm{mg} / \mathrm{ml})$ dan

6. Kelompok P3 (Paraquat 20mg/BB + EEJM $18 \mathrm{mg} / \mathrm{ml})$.

Paraquat diberikan 2 kali dalam seminggu selama 21 hari, sedangkan ekstrak etanol jahe merah diberikan selama 35 hari.

\section{Pembuatan preparat tubulus semini- ferus}

Proses pembuatan preparat dilakukan di Balai Veteriner Lampung dengan pewarnaan Hematoksilin dan Eosin.

\section{Pengamatan dan perhitungan jumlah sel spermatogenik}

Pengamatan sel spermatosit dan sel spermatid menggunakan mikroskop dengan perbesaran 400x.

\section{Analisis data}

Analisis data dilakukan menggunakan One Way ANOVA $(\alpha=5 \%)$, apabila terdapat perbedaan yang nyata maka dilanjutkan Uji Beda Nyata Terkecil (BNT) pada taraf nyata $5 \%$.

\section{HASIL DAN PEMBAHASAN}

\section{Hasil}

Jumlah sel spermatosit mencit dapat dilihat pada tabel 1.

Tabel 1. Jumlah sel spermatosit mencit pada masing-masing kelompok perlakuan

\begin{tabular}{|c|c|}
\hline \multirow[t]{2}{*}{ Perlakuan } & $\begin{array}{c}\text { Rerata Jumlah } \\
\text { Sel Spermatosit }\end{array}$ \\
\hline & $X \pm S D$ \\
\hline K (Kontrol) & $142,35 \pm 35,42^{\mathrm{ab}}$ \\
\hline $\mathbf{J}($ Jahe $18 \mathrm{mg} / \mathrm{ml})$ & $167,30 \pm 38,47^{a}$ \\
\hline $\begin{array}{l}\mathrm{Pq} \text { (Paraquat } 0,6 \\
\mathrm{mg} / \mathrm{BB})\end{array}$ & $77,20 \pm 25,91^{c d}$ \\
\hline $\begin{array}{l}\text { P1 (Pq 0,6 mg/BB + } \\
\text { EEJM } 6 \text { mg/ml } \\
(200 \mathrm{mg} / \mathrm{kgbb}))\end{array}$ & $93,95 \pm 9,07^{c}$ \\
\hline $\begin{array}{l}\text { P2 (Pq 0,6 mg/BB + } \\
\text { EEJM } 12 \mathrm{mg} / \mathrm{ml} \\
(400 \mathrm{mg} / \mathrm{kgbb}))\end{array}$ & $123,20 \pm 26,12^{b}$ \\
\hline $\begin{array}{l}\text { P3 (Pq 0,6 mg/BB + } \\
\text { EEJM } 18 \mathrm{mg} / \mathrm{ml}(600 \\
\mathrm{mg} / \mathrm{kgbb}))\end{array}$ & $138,80 \pm 24,94^{a b}$ \\
\hline
\end{tabular}

Pada tabel 1 dapat dilihat bahwa adanya perbedaan bermakna $(p<0,05)$ pada kelompok kontrol $(\mathrm{K})$ terhadap kelompok Pq, P1 dan P2. Kemudian pada kelompok $\mathrm{J}$ terhadap kelompok $\mathrm{Pq}, \mathrm{P} 1$ dan P2. Selanjutnya perbedaan bermakna juga terdapat pada kelompok Pq terhadap P1, P2 dan P3. Perbedaan tidak bermakna terdapat pada kelompok $\mathrm{Pq}$ terhadap $\mathrm{P} 1$ dan kelompok $\mathrm{P} 2$ terhadap P3.

Berdasarkan data hasil penelitian dari rata-rata jumlah sel spermatosit mencit jantan mengalami penurunan jumlah pada kelompok paraquat $(\mathrm{Pq})$ dibandingkan dengan kelompok kontrol (K), setelah itu terjadi peningkatan kembali pada kelompok P1, P2 dan P3. Namun pada kelompok jahe (J) memilki rata rata jumlah sel spermatosit tertinggi 
dibandingkan dengan semua kelompok perlakuan.

Jumlah sel spermatid mencit dapat dilihat pada tabel 2.

Tabel 2. Jumlah sel spermatid mencit pada masing-masing kelompok perlakuan

\begin{tabular}{|c|c|}
\hline \multirow{2}{*}{ Perlakuan } & $\begin{array}{l}\text { Rerata Jumlah } \\
\text { Sel Spermatid }\end{array}$ \\
\hline & $X \pm S D$ \\
\hline K (Kontrol) & $182,55 \pm 23,67^{a}$ \\
\hline $\mathbf{J}$ (Jahe $18 \mathrm{mg} / \mathrm{ml})$ & $172,60 \pm 27,59^{a}$ \\
\hline $\begin{array}{l}\mathrm{Pq} \text { (Paraquat } 0,6 \\
\mathrm{mg} / \mathrm{BB})\end{array}$ & $94,85 \pm 10,04^{b}$ \\
\hline $\begin{array}{l}\mathrm{P} 1(\mathrm{Pq} 0,6 \mathrm{mg} / \mathrm{BB}+ \\
\text { EEJM } 6 \mathrm{mg} / \mathrm{ml}(200 \\
\mathrm{mg} / \mathrm{kgbb}))\end{array}$ & $102,35 \pm 8,58^{b}$ \\
\hline $\begin{array}{l}\text { P2 (Pq 0,6 mg/BB + } \\
\text { EEJM } 12 \mathrm{mg} / \mathrm{ml}(400 \\
\mathrm{mg} / \mathrm{kgbb}))\end{array}$ & $123,35 \pm 6,86^{b}$ \\
\hline $\begin{array}{l}\text { P3 (Pq 0,6 mg/BB + } \\
\text { EEJM } 18 \mathrm{mg} / \mathrm{ml}(600 \\
\mathrm{mg} / \mathrm{kgbb}))\end{array}$ & $165,75 \pm 55,37^{\mathrm{a}}$ \\
\hline
\end{tabular}

Pada tabel 2 dapat dilihat adanya perbedaan bermakna $(p<0,05)$ pada kelompok kontrol $(\mathrm{K})$ terhadap kelompok $\mathrm{Pq}, \mathrm{P} 1$ dan P2. Kemudian pada kelompok $\mathrm{J}$ terhadap kelompok $\mathrm{Pq}, \mathrm{P} 1$ dan P2. Perbedaan tidak bermakna terdapat pada kelompok $\mathrm{K}$ terhadap $\mathrm{J}$ dan kelompok Pq terhadap P1. Dengan demikian, nilai rata rata jumlah sel spermatid terendah adalah pada kelompok paraquat (Pq). Sedangkan, pada kelompok kontrol (K) menunjukan peningkatan jumlah sel spermatid tertinggi. Kelompok kontrol juga tidak berbeda nyata pada kelompok jahe (J), akan tetapi menunjukan perbedaan bermakna pada kelompok lainnya.

\section{Gambaran histologi tubulus seminiferus}

Hasil histopatologi testis mencit dengan perhitungan jumlah sel spermatogenik menggunakan lima lapang pandang (Gambar 1), terbukti bahwa pemberian herbisida paraquat melalui oral dapat mengakibatkan penurunan jumlah sel spermatosit dan sel spermatid. Hal ini disebabkan herbisida paraquat yang masuk kedalam tubuh akan menyebabkan induksi toksisitas dikarenakan kemampuannya untuk mempengaruhi siklus redoks dan membentuk Reactive Oxygen Species (ROS). ROS terdiri dari yang bersifat

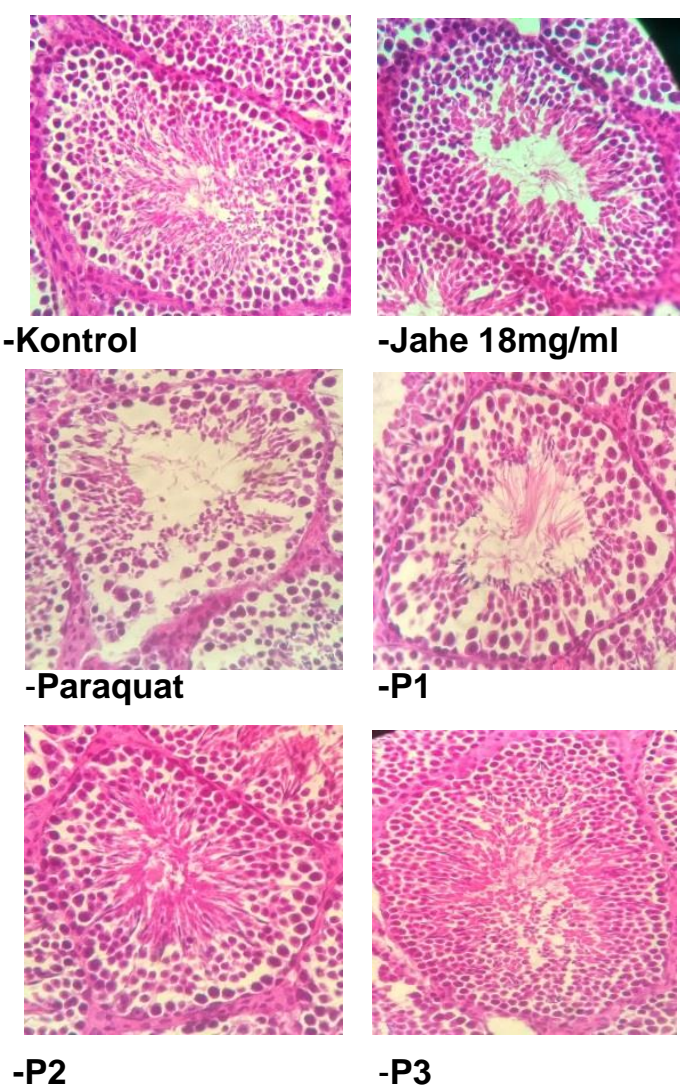

Gambar 1. Histologi tubulus seminiferus mencit jantan pada masingmasing kelompok perlakuan

radikal (hydroxyl ion, superoxyde, nitric oxid, peroxyl) dan non radikal (ozone, singletoxygen, lipid peroxide, hydrogen peroxide). Paraquat termasuk ROS jenis lipidperoksida sehingga mekanisme paraquat mengganggu spermatogenesis yaitu dengan proses peroksida lipid (Kartikeya, 2009).

Terbentuknya lipid peroksidase dapat menyebabkan gangguan fungsi sel membran dan mencetuskan apoptopsis. Lipid peroksidase juga dianggap sebagai salah satu kunci utama proses patofisiologi pertama kali pada intoksikasi paraquat. Oleh karena itu terjadinya perubahan struktur dan 
fungsi sel lipid dan protein menyebabkan hilangnya regulasi intra seluler oleh kalsium adenosine trifosfatase $\left(\mathrm{Ca}^{2+}\right.$ ATPase). Hilangnya regulasi ini dapat menyebabkan kematian sel, sehingga menyebabkan kerusakan lokal dan disfungsi organ (Indika \& Buckley, 2011).

Terbentuknya peroksidasi lipid dapat menyebabkan gangguan sintesis dan sekresi $\mathrm{GnRH}$ hipotalamus. Kegagalan ini akan menyebabkan kegagalan hipofisis untuk melakukan sintesis dan sekresi FSH maupun LH. Selanjutnya, akan diikuti oleh kegagalan sel leydig mensintesis testosteron dan sel sertoli tidak mampu melakukan fungsinya sebagai nurse cell (Nugroho, 2007).

Pemberian dosis paraquat sebanyak 20 $\mathrm{mg} / \mathrm{kgbb}$ secara oral dapat menyebabkan penurunan jumlah sel spermatogenik. Hal ini disebabkan oleh kadar radikal bebas yang terdapat pada paraquat menyebabkan menurunnya produksi hormon $\mathrm{LH}$ dan $\mathrm{FSH}$ yang merangsang pembentukan hormon testoteron. Testoteron menurun dan akhirnya spermatogenesis pun ikut terhambat sehingga menurunkan jumlah sel spermatosit dan sel spermatid (Mostafa, 2010).

Pada tabel 1 dan 2 menunjukkan pada pemberian dosis tunggal ekstrak jahe merah sebanyak $600 \mathrm{mg} / \mathrm{kgBB}$ berpengaruh dalam proses pembentukan sel-sel spermatogenik dengan menunjukkan peningkatan rata-rata jumlah sel spermatosit dan spermatid, namun pada sel-sel spermatid peningkatan jumlah sel tidak lebih besar daripada kelompok kontrol. Sedangkan pada mencit yang diberikan dosis ekstrak jahe merah sebanyak 200 $\mathrm{mg} / \mathrm{kgBB}, \quad 400 \mathrm{mg} / \mathrm{kgBB}$ dan 600 $\mathrm{mg} / \mathrm{kgBB}$ yang sebelumnya telah diinduksi herbisida paraquat dengan dosis $20 \mathrm{mg} / \mathrm{kgBB}$ menunjukkan hasil jumlah sel spermatogenik yang tampak mengalami perbaikan berupa peningkatan dibandingkan dengan kelompok yang hanya diinduksi paraquat saja. Hal ini terjadi karena jahe merah memiliki kandungan antioksidan yang bekerja menangkap radikal bebas. Kandungan aktif jahe merah yang berfungsi sebagai antioksidan diantaranya gingerol, shogaol, zingibrene, gingerdiol, dan zingerone. Zat-zat ini mampu mencegah kerusakan yang diakibatkan oleh radikal bebas. Ekstrak jahe merah mampu mencegah terjadinya peroksidasi lipid dengan cara membantu aktivitas enzim-enzim antioksidan endogen seperti superoxide dismutase, catalase, dan gluthtione peroxides pada tikus (Khaki dkk., 2009).

Jahe merah berpengaruh positif terhadap kelompok mencit yang diinduksi herbisida paraquat. Namun pada pemberian dosis ekstrak jahe merah sebanyak $200 \mathrm{mg} / \mathrm{kgBB}$ dan 400 $\mathrm{mg} / \mathrm{kgBB}$ tidak terlalu berpengaruh terhadap peningkatan jumlah sel spermatosit maupun sel spermatid, sebab pada dosis $200 \mathrm{mg} / \mathrm{kgBB}-400$ $\mathrm{mg} / \mathrm{kgBB}$ masih merupakan dosis efektif.

Setelah dilakukan perhitungan terhadap jumlah sel-sel spermatosit dan spermatid bila dibandingkan pada sel-sel spermatid memiliki peningkatan jumlah rerata sel yang lebih tinggi dibanding jumlah sel sel spermatosit. Namun secara mikroskopis terlihat pada mencit yang diberikan ektrak etanol jahe merah sebanyak 200 $\mathrm{mg} / \mathrm{kgBB}$ yang telah diinduksi paraquat sebelumnya menunjukkan gambaran tubulus seminiferus pada histologi testis mencit masih terdapat perubahan renggangnya susunan sel spermatogenik. Kerusakan serta penurunan jumlah sel-sel spermatogenik terjadi karena penurunan hormon testoteron. Sebab pada perkembangan sel spermatogenik dipengaruhi oleh hormon testoteron dan FSH (Barlett, 1989).

Sedangkan pada pemberian dosis eksrak jahe sebanyak $400 \mathrm{mg} / \mathrm{kgBB}$ dan $600 \mathrm{mg} / \mathrm{kgBB}$ secara mikroskopis terlihat adanya perbaikan susunan pada sel. Hal ini terjadi dikarenakan kerja dari efek salah satu kandungan yang terdapat pada jahe merah adalah arginin. Srivasta et al., (2006) menyatakan bahwa jahe 
merah memiliki kandungan khusus yaitu arginin yang merupakan asam amino non-esensial. Arginin merupakan prekursor dari Nitrit Oxide (NO) endogen. Arginin dipecah oleh suatu enzim bernama Nitrit Oxide Synthases (NOS) menjadi citrulline dan NO. Nitrit Oxide yang dihasilkan arginin berperan penting terhadap spermatozoa yaitu pertama berperan meningkatkan motilitas spermatozoa dengan cara meningkatkan metabolisme dan menghasilkan ATP lebih banyak, selanjutnya ATP digunakan sebagai sumber energi motilitas spermatozoa. Selain itu arginin juga berperan melindungi membran aksonema dari proses peroksidase lipid yang disebabkan oleh stress oksidatif.

\section{KESIMPULAN}

Pemberian herbisida paraquat mengakibatkan penurunan jumlah sel-sel spermatogenik, baik pada sel spermatosit maupun sel spermatid pada tubulus seminiferus mencit jantan. Pemberian ektrak etanol jahe merah (Zingiber officinale Roxb. var. rubrum) dosis $6 \mathrm{mg} / \mathrm{ml}, 12 \mathrm{mg} / \mathrm{ml}$ dan $18 \mathrm{mg} / \mathrm{ml}$ dapat menyebabkan peningkatan jumlah sel spermatosit dan sel spermatid mencit jantan yang diinduksi herbisida paraquat diklorida. Pemberian ekstrak etanol jahe merah (Zingiber officinale Roxb. var. rubrum) pada dosis $18 \mathrm{mg} / \mathrm{ml}$ memberikan peningkatan jumlah rerata sel spermatosit dan spermatid baik pada pemberian dosis tunggal maupun pada mencit yang telah diinduksi herbisida paraquat diklorida.

\section{DAFTAR PUSTAKA}

Ali, B.H., Blunden, G., Tanira, M.O. dan Nemmar, A. (2008). Some Phytochemical, Pharmacological and Toxicological Properties of Ginger (Zingiber officinale Roscoe). $A$ review of recent research. Food Chem Toxicol (46), 409-420.

Hardjopranoto, S. (1995). IImu Kemajiran pada Ternak. Surabaya: Airlangga University Press.
Indika G, Buckley N. (2011). Medical management of paraquat ingestion. British Journal of Clinical Pharmacology: University of New South Wales, Sydney, Australia. Diakses dari: http://www.ncbi.nlm.noh.gov/.

Khaki A, Fathiazad F, Nouri M, Amir K, Ozanci C, Novin G, dkk. (2009). The effect of ginger on spermatogenesis and sperm parameters of rat. Iranian Journal of Reproductive Medicine, 7, 7-12.

Mostafa MH, Osfor, Ibrahim HS, Mohamed YA, Ahmed SM, Azeem ASAE, \& Hegazy AM. (2010). Effect of Alpha Acid and Vitamin $E$ on Heavy Metals Intoxication in Male Albino Rats. Journal of American Science, 6(8), 56-63.

Nugroho, CA. (2007). Pengaruh minuman beralkohol terhadap jumlah lapisan sel spermatogenik dan berat vesikula seminalis mencit. Widya Warta Jurnal IImiah Universitas Katolik Widya Mandala Madiun, 33(1).

Palaniyappan, V., Bommireddy, E.P., Gudipudi, H., Chitturi, R.D., Yandamala, N. (2013). In Vivo Fertility Enhancing Activity (Aprodisiac) of Ficus Carica Fruit on Male Wistar Rats. International Journal of Pharmacy and Pharmaceutical Sciences, 5(2), 516518.

Prijanto, TB. (2009). Analisis faktor resiko keracunan pestisida organofosfat pada keluarga petani holtikultura di Kecamatan Ngablak Kabupaten Magelang (Tesis). Semarang: Universitas Diponegoro.

Srivasta, S., Desai, P., Coutinho, E., Govil, G. (2006). Mechanism of Action of L-Arginine on the Vitality of Spermatozoa is Primarily Through Increased Biosynthesis of Nitric Oxide. Tata Institute of Fundamental 
Research. India. Biology of Reproduction Journal, 74, 954-958.

Sriyani, N., dan A.K Salam. (2008). Penggunaan metode bioassay untuk mendeteksi pergerakan herbisida pascatumbuh paraquat dan 2,4-D dalam tanah. Jurnal Tanah Tropika, 13(3), 199-208. 